\title{
A rare case report of Poland syndrome in neonates
}

\author{
Kumar $\mathbf{P}^{1}$, Bhatia $\mathbf{M}^{2}$, Sharma $\mathbf{C M}^{3}$ \\ ${ }^{1}$ Dr Prashant Kumar, Resident in Pediatrics, From Department of Pediatrics, ${ }^{2}$ Dr Manvi Bhatia, From Department of \\ Pediatrics, Dr C M Sharma, Assistant Professor, From Department of Paediatrics. All are Subharti Medical College, \\ Meerut, UP, India
}

Address for Correspondence: Dr Prashant kumar, Resident in Pediatrics, From Department of Pediatrics, Subharti Medical College, Meerut. Email: prashant_kumar_28@yahoo.co.in

\begin{abstract}
The Poland's anomaly was first described in 1841 by Sir Alfred Poland as a syndrome presenting with absence or underdevelopment of pectoralis major muscle, associated in some cases with a hypoplasia of the breast, an agenesis of 2, 3, 4 and 5 ipsilateral costal cartilages, and an ipsilateral webbing of the fingers (cutaneous syndactyly). Other associated abnormalities may include dextrocardia, diaphragmatic hernia and renal anomalies etc. Poland syndrome most often affects the right side of the body, and occurs more often in males than in females. It is usually considered a unilateral condition but rarely, bilateral.
\end{abstract}

\section{Introduction}

It was first named in 1962 by Patrick Clarkson, a New Zealand-born British plastic surgeon. The incidence of this condition ranges from 1: 20,000 to 1:50,000 live births as reported by different authors $[1,2]$.

The cause of Poland syndrome is unknown. However, an interruption of the embryonic blood supply to the arteries that lie under the collarbone (subclavian arteries) at about the 46th day of embryonic development is the prevailing theory. Although several theories of etiogenesis have been proposed, the vascular theory appears to be the most favoured by many [3]

\section{Case Report}

A newborn, preterm (34 wks POG) male presented at Subharti medical college at 6 hours of life born via LSCS (cause leaking PV since 2 days and oligohydramnios) for ongoing care of prematurity. Baby cried immediately after birth and no signs of distress present. The baby was first issue of non consanguineous marriage. No significant Natal history present except PV leaking.

On examination pulse was 136 per minute, BP 44/26(34) mm of hg, Length $48 \mathrm{cms}$, weight $1.810 \mathrm{kgs}$

\footnotetext{
Manuscript received: $14^{\text {th }}$ Oct 2015

Reviewed: $24^{\text {th }}$ Oct 2015

Author Corrected: $10^{\text {th }}$ Nov 2015

Accepted for Publication: $27^{\text {th }}$ Nov 2015
}

and Head circumference $35 \mathrm{cms}$ were noted. There was some abnormality of right side of chest with asymmetrical hypoplasia and absence of anterior axillary fold [Figure 1]. Ipsilateral fingers were short and webbed (symbrachydactyly) [Figure 2]. No systemic abnormality was noted.

Xray chest showed no abnormalities of the ribs or heart but increased translucency over the ride side due to the absence of pectoralis major muscle [Figure 3] and Xray of the affected limb showed aplasia of the $1^{\text {st }}$ to 4 th fingers. Axial computed tomography scan showed the presence of pectoralis major on the left side but not on the Right [Figure 4].

\section{Discussion}

The case of Poland Syndrome we present is the first described in Rwanda and is of the pure presentation as it consists only on the unilateral aplasia of the pectoralis major muscle without any other associated defects $[1,4]$. The cause of Poland syndrome is uncertain and it often occurs sporadically. The disorder is currently considered "a non-specific developmental field defect" occurring at about the $6^{\text {th }}$ week of fetal development.

Geneticists currently hold the view that Poland syndrome is rarely inherited and generally is a sporadic event. There are rare instances where more than one 
individual has been identified with Poland syndrome either in the immediate $[5,6,7]$ or extended family. [8, $9,10]$ Therefore, some authors believe that an inherited

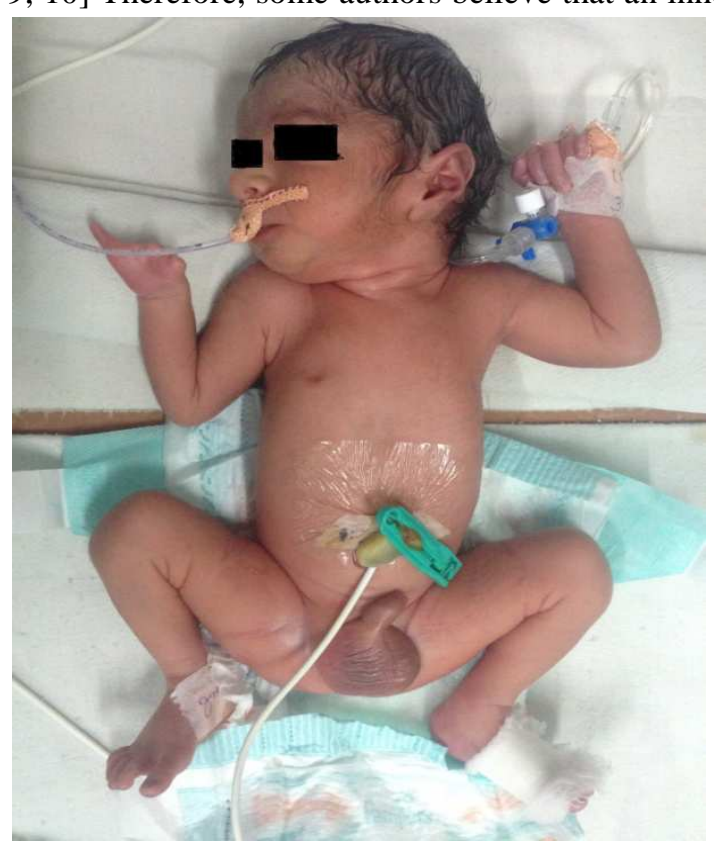

Fig 1: Showing some abnormality of right side of chest with asymmetrical hypoplasia and absence of anterior axillary fold

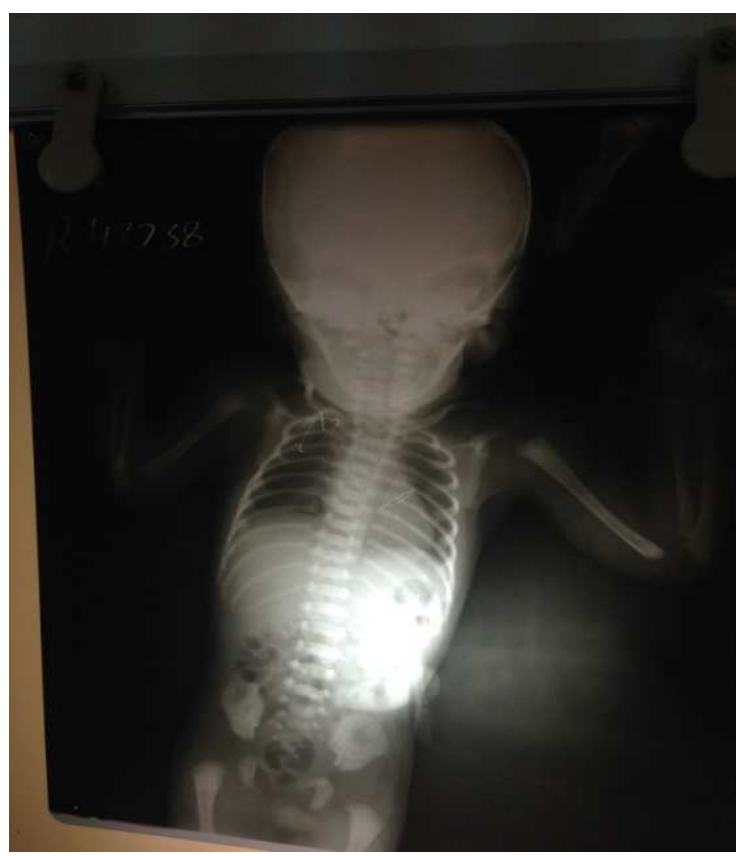

Fig 3: Xray showing increased translucency over the ride side

\section{Conclusion}

It is a rare inherited disorder with aplasia of pectoralis major muscle on either side with or without associated abnormal vasculature formation may be the central underlying mechanism for this condition.

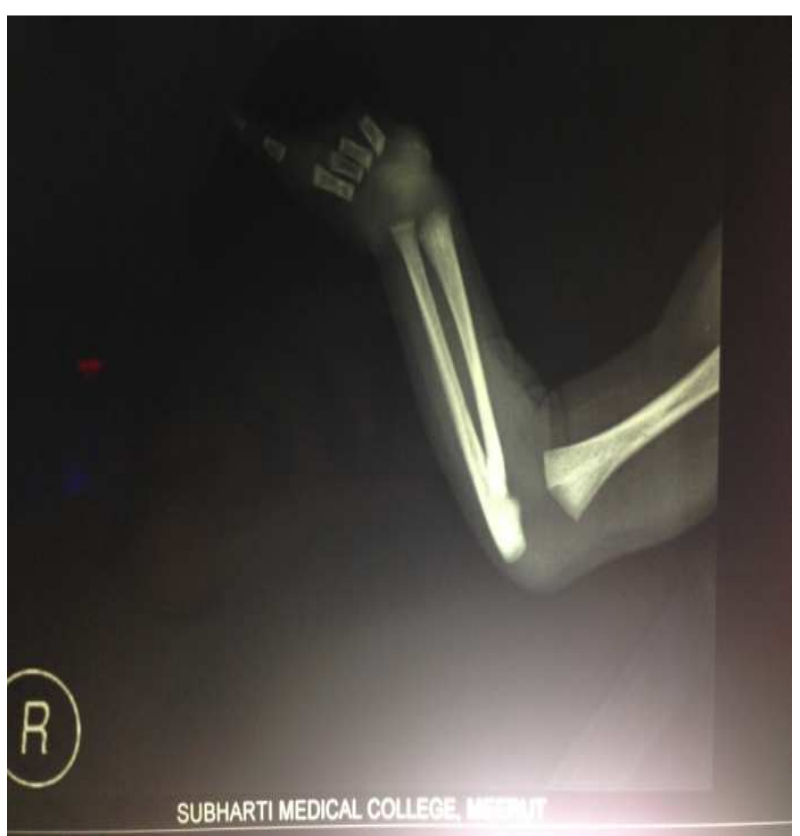

Fig 2: Xray showing ipsilateral fingers were short and webbed

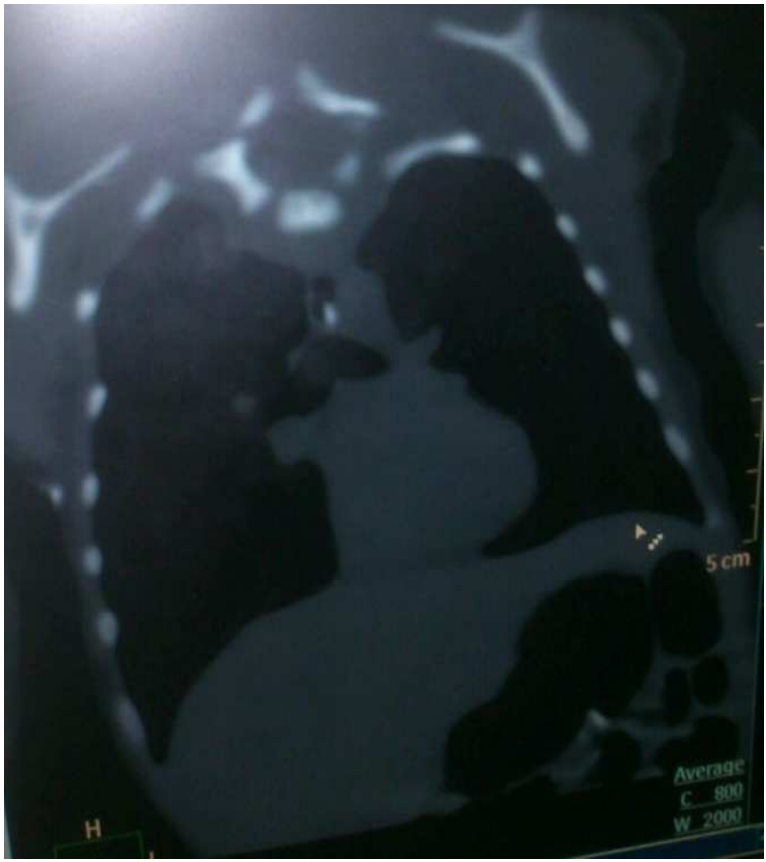

Fig 4: Showing presence of pectoralis major on the left side and absent on right side.

disorders. A team approach is required for management of patient with Poland syndrome. Several reconstructive procedures are available to correct the functional and 
structural deformities associated with this syndrome. As for the chest deformity, customized silicone prosthesis is simply and safely used. Transposition of the latissimus dorsi muscle for soft-tissue reconstruction has been used by many authors with satisfactory esthetic and functional results [11].

Funding: None, Competing interests: None declared Ethical clearance: The study was approved by the institutional human ethical committee

\section{References}

1. Fokin AA, Robicsek F. Poland's syndrome revisited. Ann Thorac Surg. 2002 Dec;74(6):2218-25.

2. Legbo JN. Poland's syndrome: report of a variant. J Natl Med Assoc. 2006 Jan;98(1):97-9.

3. Bavinck JN, Weaver DD. Subclavian artery supply disruption sequence: hypothesis of a vascular etiology for Poland, Klippel-Feil, and Möbius anomalies. Am J Med Genet. 1986 Apr;23(4):903-18.

4. Ferraro GA, Perrotta A, Rossano F, D'Andrea F. Poland syndrome: description of an atypical variant. Aesthetic Plast Surg. 2005 Jan-Feb;29(1):32-3. Epub 2005 Mar 10.
5. Cobben JM, Robinson PH, van Essen AJ, van der Wiel HL, ten Kate LP. Poland anomaly in mother and daughter. Am J Med Genet. 1989 Aug;33(4):519-21.

6. Czeizel A, Vitéz M, Lenz W. Birth prevalence of Poland sequence and proportion of its familial cases. Am J Med Genet. 1990 Aug;36(4):524.

7. Hoyme HE, Der Kaloustian VM, Hogg H, Entin MA, Guttmacher AE. Possible common pathogenetic mechanisms for Poland sequence and Adams-Oliver syndrome: an additional clinical observation. Am J Med Genet. 1992 Feb 1;42(3):398-9.

8. David TJ. Familial Poland anomaly. J Med Genet. 1982 Aug;19(4):293-6.

9. Lowry RB, Bouvet JP. Familial Poland anomaly. J Med Genet. 1983 Apr;20(2):152-4.

10. Fraser FC, Ronen GM, O'Leary E. Pectoralis major defect and Poland sequence in second cousins: extension of the Poland sequence spectrum. Am J Med Genet. 1989 Aug;33(4):468-70.

11. Freitas Rda S, o Tolazzi AR, Martins VD, Knop BA, Graf RM, Cruz GA. Poland's syndrome: different clinical presentations and surgical reconstructions in 18 cases. Aesthetic Plast Surg. 2007 Mar-Apr;31(2):140-6.

\section{How to cite this article?}

Kumar P, Bhatia M, Sharma CM. A rare case report of Poland syndrome in neonates. Int J Med Res Rev 2015;3(10):1273-1275. doi: 10.17511/ijmrr.2015.i10.231. 